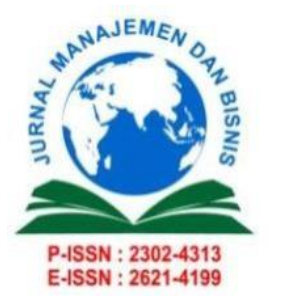

Jurnal Manajemen dan Bisnis

Vol. 10, No. 2, December 2021, pp. 1-11

Sekolah Tinggi Ilmu Ekonomi Indragiri (STIE-I) Rengat

https://journal.stieindragiri.ac.id/index.php/jmbi/issue/view/20

\title{
THE INFLUENCE OF WORKLOAD, NON-PHYSICAL WORK ENVIRONMENT, COMPENSATION ON EMPLOYEE TURNOVER MEDIATED WITH ORGANIZATIONAL COMMITMENT
}

\author{
Andi Saputra ${ }^{1)}$ Sri Indarti ${ }^{2)}$ Yulia Efni ${ }^{3)}$ \\ 1) 2) 3) University of Riau, Faculty of Economics and Business, Jl Pattimura No 9 Pekanbaru \\ andysaputra6194@gmail.com
}

Submited: 2021.09.27 Reviewed: 2021.11.20 Accepted: 2021.12.31

https://doi.org/10.34006/jmbi.v10i2.305

\begin{abstract}
The research was conducted at PT Lutvindo Wijaya Perkasa Pekanbaru. The aim is to determine the direct effect of workload, non-physical work environment, compensation for employee turnover mediated by organizational commitment. This study took a sample of 160 customers. The variables used are workload, non-physical work environment, compensation for employee turnover mediated by organizational commitment. The data were analyzed using SEM (Structural Equation Modeling) analysis which was operated through the Smart PLS 3.2.8 . programThe results of the study indicate that there are Workload has a significant effect on employee turnover in PT. Lutvindo WijayaNonphysical work environment, Compensation, organizational commitment and workload have a significant effect on employee turnover with organizational commitment as a mediating variable.Every increase in workload will increase employee turnover, and every decrease in workload will decrease employee turnover with organizational commitment as a mediating variable. Nonphysical work environment has a significant effect on employee turnover with organizational commitment as a mediating variable. The better the non-physical work environment will reduce employee turnover, and the worse the non-physical work environment will increase employee turnover with organizational commitment as a mediating variable.Compensation has a significant effect on employee turnover with organizational commitment as a mediating variable. The greater the compensation received will reduce employee turnover, and the smaller the compensation received will increase employee turnover with organizational commitment as a mediating variable.
\end{abstract}

\section{Keywords: Workload, Non-Physical Work Environment, Compensation, Turnover and} Organizational Commitment

\section{INTRODUCTION}

Human resources have a big role for the success of an organization, currently human resources have entered into the company's important assets. Therefore, many companies invest in building superior human resources to be able to compete with other companies. Building the right human resources is very important, because if it is not managed properly it can lead to a high level of employee turnover for company employees.

Chen et al (2010:132) Employee turnover has been an important issue for decades. According to Robbins and Judge (2013:79), employee turnover is a permanent dismissal of employees from the company, whether carried out by the employees themselves voluntarily or by the company. Employee turnover can also be in the form of resignation, transfer out of 
the organizational unit, dismissal or death of a member of the organization or company. The high level of employee turnover can interfere with the strategy that has been designed by the company. Because every staff position that has been designed must go through an assessment process carried out by the company's assessment team.

Mobley (2011:121) Employee turnover is influenced by several factors including workload, non-physical work environment, compensation, organizational commitment and leadership. According to Staffelbach (2014: 13) says that employee turnover is influenced by organizational commitment and job satisfaction, including remuneration, social integration, formal communication, employee centralization, work routines that tend to burnout, excessive roles or tasks, promotion opportunities and career development, general training, supervisor support, peer support and fair distribution.

One of the factors that affect employee turnover is workload, the average company provides workloads to its employees for 8 hours / day and when the work cannot be completed it will be charged the next day, except for the type of work that is required to be completed on the same day. So, employees are required to run overtime until the work is completed. That way, the phenomenon that exists in the company is that there are several employees who feel the impact that they have to work overtime for days at a time, due to work piling up from the field and work that should be done by 3 people, but only done by 1-2 people. So, sometimes you have to sacrifice vacation time with family.

Soleman (2011:85)Workload is the amount of work given by the organization or company that must be done by its employees. The workload is quantitatively measured based on the time to be completed, while qualitatively the workload can cause mental pressure on employees. According to Putra (2012:22) a high workload can be detrimental to employees and the organization, because if the workload given by the employee is too high while the employee's ability cannot meet work demands, the organization will need additional time so that the employee can complete his work.

\section{RESEARCH METHODOLOGY RESEARCH SITES}

This research was conducted at PT Lutvindo Wijaya Perkasa Pekanbaru

\section{TYPES OF RESEARCH}

The type of research used in this research is descriptive method and associative method by asking casual (cause-and-effect) relationships. This research was conducted with a quantitative research approach, namely the researcher used questionnaires, observations, and interviews in conducting data collection techniques.

\section{POPULATION AND SAMPLE}

According to (Sugiyono, 2013), population is a generalization area consisting of objects/subjects that have certain qualities and characteristics that are applied by researchers to be studied and then drawn conclusions.

Based on the above understanding, the population in this study is all PT Lutvindo Wijaya PerkasaPekanbaru in 2021, totaling 160 people. the sample in this study was a saturated sample and a sample of 160 respondents with an error rate of $10 \%$.

\section{HYPOTHESIS TEST}

After conducting various evaluations, both the outer model and the inner model, the next step is to test the hypothesis. Hypothesis testing is used to explain the direction of the 
relationship between the independent variable and the dependent variable. This test is carried out by means of SEM technique analysis

\section{RESEARCH RESULTS AND DISCUSSION}

Hypothesis testing using Partial Least Square (PLS) will show six hypotheses. This test is done by using the t-test (t-test) the effect between variables. In PLS statistical testing of each hypothesized relationship is carried out using simulation. In this case, the bootstrapping method was carried out on the sample, testing with bootstrapping was also intended to minimize problems with research data. The results of the bootstrapping test from the PLS analysis can be seen as follows:

Table 1: Hypothesis Testing Results

\begin{tabular}{|l|c|c|c|}
\hline \multicolumn{1}{|c|}{ Influence } & $\begin{array}{c}\text { Path } \\
\text { Coefficients }\end{array}$ & P values & Decision \\
\hline Workload $\rightarrow$ Turnover & 0.332 & $<0.001$ & Significant \\
\hline $\begin{array}{l}\text { Non-Physical Work } \\
\text { Environment } \rightarrow \text { Turnover }\end{array}$ & -0.154 & 0.023 & Significant \\
\hline Compensation $\rightarrow$ Turnover & -0.177 & 0.011 & Significant \\
\hline $\begin{array}{l}\text { Organizational } \\
\text { Commitment } \rightarrow \text { Turnover }\end{array}$ & -0.346 & $<0.001$ & Significant \\
\hline $\begin{array}{l}\text { Workload } \rightarrow \text { Organizational } \\
\text { Commitment } \rightarrow \text { Turnover }\end{array}$ & 0.125 & 0.011 & Significant \\
\hline $\begin{array}{l}\text { Non-Physical Work } \\
\text { Environment } \rightarrow \text { Organizational } \\
\text { Commitment } \rightarrow \text { Turnover }\end{array}$ & -0.126 & 0.011 & Significant \\
\hline $\begin{array}{l}\text { Compensation } \rightarrow \text { Organizational } \\
\text { Commitment } \rightarrow \text { Turnover }\end{array}$ & -0.093 & 0.045 & Significant \\
\hline
\end{tabular}

Source: Processed Data, 2021

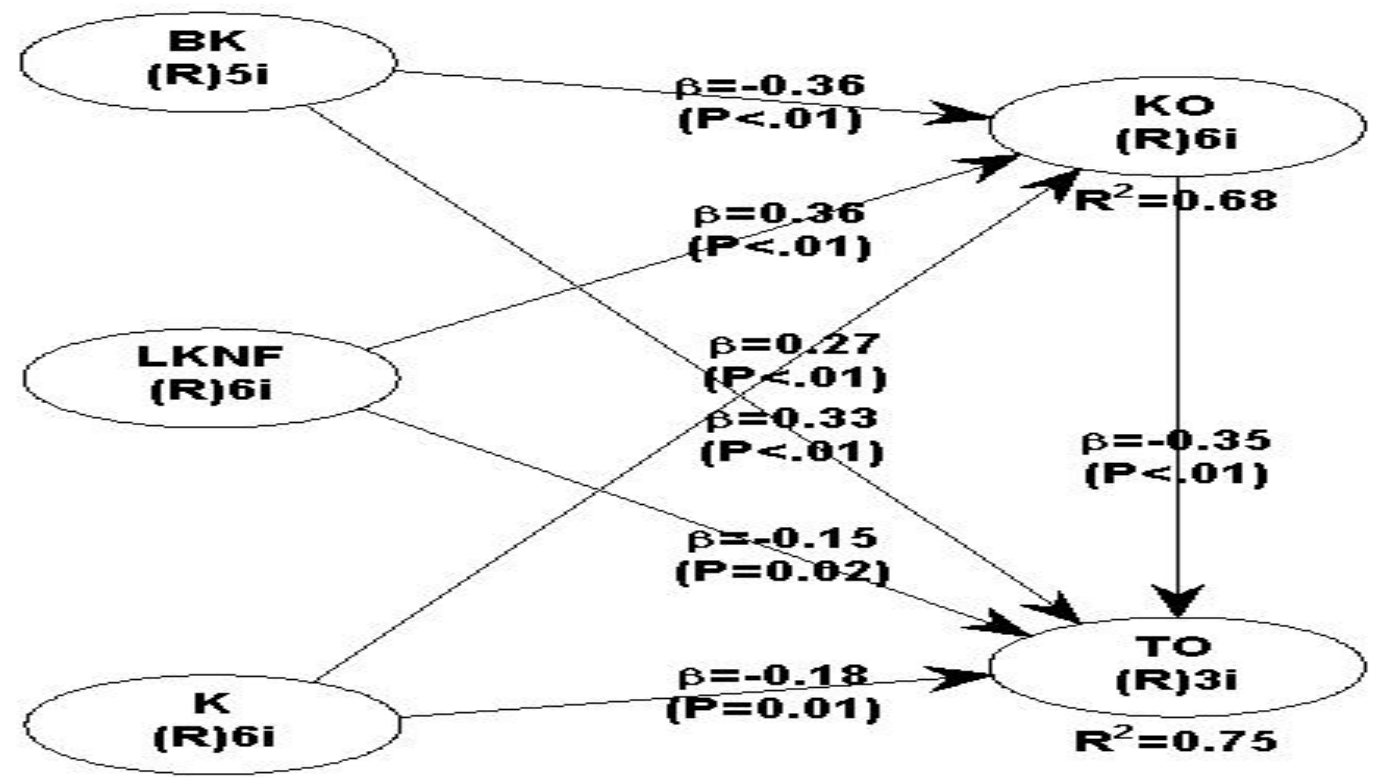




\section{DISCUSSION}

It can be seen the results of hypothesis testing as follows:

1. Workload $\rightarrow$ Turnover

Obtained Markpath coefficients equal to 0.332 Then obtained Mark $p$ value $<0.001$ which means that that workload significant effect on turnover. Thus, the hypothesis which states that workload affects employee turnover inPT. Lutvindo Wijaya Perkasa "accepted".

2. Non Physical Work Environment $\rightarrow$ Turnover

Obtained Markpath coefficients of -0.153 Then obtained Mark $p$ value of $0.023<0.05$ which means that that the non-physical work environment significant effect on turnover. Thus, the hypothesis which states that the non-physical work environment affects employee turnover inPT. Lutvindo Wijaya Perkasa "accepted".

3. Compensation $\rightarrow$ Turnover

Obtained Markpath coefficients of -0.177 Then obtained Mark $p$ value of $0.023<0.05$ which means that that compensation significant effect on turnover. Thus, the hypothesis which states that compensation has an effect on employee turnover inPT. Lutvindo Wijaya Perkasa "accepted".

4. Organizational Commitment $\rightarrow$ Turnover

Obtained Markpath coefficients of -0.346 Then obtained Mark $p$ value $<0.001$ which means that that organizational commitment significant effect on turnover. Thus, the hypothesis which states that organizational commitment has an effect on employee turnover inPT. Lutvindo Wijaya Perkasa "accepted".

5. Workload $\rightarrow$ Organizational Commitment $\rightarrow$ Turnover

Obtained Markpath coefficients equal to 0.125 Then obtained Mark $p$ value of $0.011<$ 0.05 which means that that workload significant effect on turnover with organizational commitment as a mediating variable. Thus, the hypothesis which states that workload affects employee turnover is mediated by organizational commitment toPT. Lutvindo Wijaya Perkasa "accepted".

6. Non-Physical Work Environment $\rightarrow$ Organizational Commitment $\rightarrow$ Turnover Obtained Markpath coefficients of -0.126 Then obtained Mark $p$ value of $0.011<0.05$ which means that that the non-physical work environment significant effect on turnover with organizational commitment as a mediating variable. Thus, the hypothesis which states that the non-physical work environment affects employee turnover is mediated by organizational commitment toPT. Lutvindo Wijaya Perkasa "accepted".

7. Compensation $\rightarrow$ Organizational Commitment $\rightarrow$ Turnover

Obtained Markpath coefficients of -0.093 Then obtained Mark $p$ value of $0.045<0.05$ which means that that compensation significant effect on turnover with organizational commitment as a mediating variable. Thus, the hypothesis which states that compensation has an effect on employee turnover is mediated by organizational commitment toPT. Lutvindo Wijaya Perkasa "accepted".

\section{DISCUSSION}

\section{EFFECT OF WORKLOAD ON EMPLOYEE TURNOVER}

Every job is a burden for the person concerned, both physically and mentally. Workload is a condition where workers are faced with tasks that must be completed at a certain time. Another category of workload is a combination of quantitative and qualitative workloads. Quantitative workload that arises because the tasks are too many or too few. While the qualitative workload, if the worker feels unable to carry out the task or task does not use the skills or potential of the worker. Excessive workload will cause fatigue both 
physically and mentally. Meanwhile, too little workload will cause boredom and a sense of monotony.From the results of the study, it was found that the workload significant effect on employee turnover in PT. Lutvindo Wijaya Perkasa. These results also show that workload has a positive effect on employee turnover. This means that the higher the workload given to employees, the more turnover will increase and vice versa, the lower the workload given, the lower the turnover will be.

The results of this study are in line with research conducted by Firda Widiawati et al. (2017) with the results of research that workload has a positive and significant effect on employee turnover at PT. Geogiven Visi Mandiri Semarang. Then the research conducted by Hanifah Nur'aini (2018) with research results showing that the workload has a positive and significant effect on the turnover of medical representative employees in the Yogyakarta area, the greater the workload, the greater the employee turnover.

The results of the study found that the high workload felt by employees. This is because the task is generally related to the physical. Many of these employees feel that it is difficult to do physical tasks. Employees feel excessive fatigue and to the point of disturbing their health if they have to do tasks that require excessive physical strength. In addition, the demand to complete work causes work time to exceed normal time, so that many employees work too intensively, thereby reducing their rest time. This causes employees to be exhausted and unable to follow the company's way of working so that it can influence employees to change jobs or quit.

\section{INFLUENCE OF NON-PHYSICAL WORK ENVIRONMENT ON EMPLOYEE TURNOVER}

Working as an employee certainly expects the surrounding environment to support their work activities. One form of the work environment includes physical facilities. Matters related to physical facilities include work equipment, workplace, cooperation and so on. It can be understood that a good work environment will contribute to employee performance at work, so that it will create a sense of comfort and feel at home at work and can reduce and eliminate the desire and feeling to move work to another place.

From the results of the study, it was found that the work environment significant effect on employee turnover in PT. Lutvindo Wijaya Perkasa. These results also indicate that the non-physical work environment has a negative effect on employee turnover. This means that the better the non-physical work environment, the lower the turnover and vice versa, the less good the non-physical work environment, the higher the turnover.The results of this study are in line with research conducted by Retno Khikmawati (2015), Dwiningtyas (2015), and Renny Rakhma Tsani (2016) which proves that partially the work environment has a negative and significant effect on employee turnover intention.

The results of the study found that the lack of communication and interaction between fellow employees was caused by a sense of seniority so that they felt they had to be respected and the emergence of jealousy towards other employees due to the lack of equal opportunities from the company. DisaBesides that, there is also no conflict management from the company's leadership in resolving personal conflicts between employees as long as it doesn't harm the company. Companies tend not to interfere in the personal affairs of employees.

\section{EFFECT OF COMPENSATION ON EMPLOYEE TURNOVER}

Providing good compensation to employees will motivate employees to work well. The award shows that the contribution given by the employee is properly appreciated by the company, so that the employee is more motivated to work for the company. Employees who are appreciated by the company also tend to be loyal to the company. Employee turnover has a very close relationship with compensation and vice versa. If compensation is paid fairly and 
correctly, the employee's intention to leave the company can be minimized. Employees will continue to survive and do not think about leaving the company. And vice versa if compensation is not paid properly and fairly, then employees will certainly try to leave and choose a company that pays compensation as they want.

From the results of the study, it was found that compensation significant effect on employee turnover in PT. Lutvindo Wijaya Perkasa. These results also show that compensation has a negative effect on employee turnover. This means that the greater the compensation, the lower the turnover and vice versa, the smaller the compensation, the higher the turnover. The results of this study are in line with research conducted by Ridwan Suryo Pranowo (2016), Sigi Ansyar (2015), and Freza Mahaztra Sandi (2014) which proves that partially compensation has a negative and significant effect on employee turnover intention.

Overall, the compensation provided by the company to employees is good, such as the provision of bonuses, incentives and other facilities. However, the amount of salary given is stillclassified as low for employees who have groups 2 and 3, namely below the minimum wage. The company also seeks to stimulate employees by providing remuneration and facilities for employees, such as Umrah worship activities, employee recreation, social activities and educational scholarships. However, for Umrah worship and educational scholarships, not all employees can get these opportunities.

\section{THE EFFECT OF WORKLOAD ON EMPLOYEE TURNOVER THROUGH ORGANIZATIONAL COMMITMENT}

Workload is a factor related to one's work and can put pressure on people if the demands of the task are felt excessively fast and can increase anxiety and decrease one's organizational commitment.Gibson et al (1996) argue that highly variable workloads lead to a lack of organizational commitment. It is clear that the various workloads that are not in accordance with the competencies and skills possessed by employees will have an impact on the relevant organizational commitment. Someone who accepts high task demands can cause physical fatigue and decrease employee organizational commitment and in turn will lead to employee turnover. And the demands of heavy and hard tasks can cause a workload.

From the results of the study, it was found that the workload significant effect on employee turnover mediated by organizational commitment to PT. Lutvindo Wijaya Perkasa. These results also indicate that workload has a positive effect on employee turnover which is mediated by organizational commitment. This means that the higher the workload given to employees, the more turnover will increase and vice versa, the lower the workload given, the lower the turnover will be with organizational commitment as a mediating variable. The results of research conducted by Widyantara and Ardana (2017) with research results showing that workload has a significant effect on employee desire to perform Turnover Intention. Then the research of Fahrizal and Utama, Murdiarta (2017) shows that organizational commitment has a significant effect on the desire of employees to perform employee turnover. Thus, organizational commitment can indirectly affect employee turnover rates.

\section{INFLUENCE OF NON-PHYSICAL WORK ENVIRONMENT ON EMPLOYEE TURNOVER THROUGH ORGANIZATIONAL COMMITMENT}

The work environment reflects the internal conditions of an organization because the work environment can only be felt by members of the organization, and can be a means to find the causes of negative behavior that appears in employees. In order for employees to be positive in their work, a healthy and conducive work environment must be created, so that they strive to achieve organizational goals. The general characteristics of a healthy work environment include four elements. First, employees are treated with respect and fairness. 
Second, there is a mutual trust that strong relationship between management and employees. Third, have an organizational culture that support communication and collaboration, and decision making is not solely for monetary considerations, but also for consideration of the impact of decisions on the mission of the organization and its members. Fourth, encourage each individual to feel physically and emotionally safe. A good work environment (healthy, safe, comfortable and harmonious) for employees in carrying out their work will cause these employees to feel at home at work, which will lead to organizational commitment of employees and efforts to maintain their status as employees.

From the results of the study, it was found that the non-physical work environment significant effect on employee turnover mediated by organizational commitment to PT. Lutvindo Wijaya Perkasa. These results also indicate that the non-physical work environment has a negative effect on employee turnover which is mediated by organizational commitment. This means that the better the non-physical work environment felt by the employees, the lower the turnover will be and vice versa, the less the non-physical work environment felt by the employees, the higher the turnover will be with organizational commitment as a mediating variable. The results of research conducted by Laksmi S. W Irvianti and Renno Eka Verina (2015) with the results that the work environment affects employee turnover intention at PT. XL Axiata Jakarta. Then the research of Fahrizal and Utama, Murdiarta (2017) shows that organizational commitment has a significant effect on the desire of employees to perform employee turnover. Thus the work environment can indirectly affect employee turnover rates.

\section{THE EFFECT OF COMPENSATION ON EMPLOYEE TURNOVER THROUGH ORGANIZATIONAL COMMITMENT}

From the results of the study, it was found that compensation significant effect on employee turnover mediated by organizational commitment to PT. Lutvindo Wijaya Perkasa. These results also show that compensation has a negative effect on employee turnover which is mediated by organizational commitment. This means that the greater the compensation received by employees, the turnover will decrease and vice versa, the smaller the compensation felt by employees, the turnover will increase with organizational commitment as a mediating variable.The results of research conducted by Rohman (2009) which examines the Effect of Organizational Commitment on Job Satisfaction and Desire to Move. (Study of Public Accounting Firm Employees in Central Java) found that organizational commitment which includes affective commitment and continuance commitment has a negative effect on employee turnover intentions. Then the research of Fahrizal and Utama, Murdiarta (2017) shows that organizational commitment has a significant effect on the desire of employees to perform employee turnover. Thus the work environment can indirectly affect employee turnover rates.

Compensation is a response from the company received employees, both financial and non-financial. The amount of compensation received is in accordance with the work target and the workload completed will be more motivate employees to work earnestly in achieving organizational goals and objectives. In providing financial compensation, the company applies a fixed salary system that is in accordance with the position, length of service, and workload of the employee. Bonuses and incentives are given in accordance with the assessment of work performance, creativity, and attendance. Providing non-financial compensation, the company sends several employees in rotation to attend training organized by the company at a certain period of time as needed. Providing good compensation will motivate employees to commit to organizations that have fulfilled their daily needs, causing employees not to want to move to other companies. 


\section{THE EFFECT OF ORGANIZATIONAL COMMITMENT ON EMPLOYEE TURNOVER}

From the results of the study, it was found that organizational commitment significant effect on employee turnover in PT. Lutvindo Wijaya Perkasa. These results also indicate that organizational commitment has a negative effect on employee turnover. This means that the higher the organizational commitment, the lower the turnover and vice versa, the lower the organizational commitment, the higher the turnover.

According to Mobley (2011), employee turnover is influenced by several factors including organizational commitment. Sentana and Surya (2017) state that organizational commitment is an important behavioral dimension, which can be used to assess the tendency of employees to remain as members of the company. Employees who are committed to the organization will have a strong desire to remain a member of the organization, and employees will try their best in their work.According to Lee and Mowday (1987) concluded that individuals who fulfill organizational commitment will have a high level of job satisfaction and lower exit intentions.

Research Grant et al., (2001) found a negative relationship between organizational commitment and turnover intention. Employees who are dissatisfied with aspects of work who do not have organizational commitment to their organization will look for work in other organizations.

\section{CONCLUSION}

From the research results that have been described previously, the conclusions of this study can be drawn as follows:

1. Workload has a significant effect on employee turnover inPT. Lutvindo Wijaya Perkasa. Every increase in workload will increase employee turnover, and every decrease in workload will decrease employee turnover.

2. The non-physical work environment has a significant effect on employee turnover inPT. Lutvindo Wijaya Perkasa. The better the non-physical work environment will reduce employee turnover, and the worse the non-physical work environment will increase employee turnover.

3. Compensation has a significant effect on employee turnover in PT. Lutvindo Wijaya Perkasa. The greater the compensation received will reduce employee turnover, and the smaller the compensation received will increase employee turnover.

4. Organizational commitment has a significant effect on employee turnover in PT. Lutvindo Wijaya Perkasa. The higher the organizational commitment will reduce employee turnover, and the lower organizational commitment will increase employee turnover.

5. Workload has a significant effect on employee turnover with organizational commitment as a mediating variable on PT. Lutvindo Wijaya Perkasa. Every increase in workload will increase employee turnover, and every decrease in workload will decrease employee turnover with organizational commitment as a mediating variable.

6. The non-physical work environment has a significant effect on employee turnover with organizational commitment as a mediating variable on PT. Lutvindo Wijaya Perkasa. The better the non-physical work environment will reduce employee turnover, and the worse the non-physical work environment will increase employee turnover with organizational commitment as a mediating variable.

7. Compensation has a significant effect on employee turnover with organizational commitment as a mediating variable on PT. Lutvindo Wijaya Perkasa. The greater the compensation received will reduce employee turnover, and the smaller the compensation 
received will increase employee turnover with organizational commitment as a mediating variable.

\section{SUGGESTION}

From the research results and conclusions that have been described previously, the authors provide the following suggestions:

1. Job descriptions for employees of PT Lutvindo Wijaya Perkasa must be clarified, not only verbally but also in writing so that employees do not feel confused in doing their work. The company also needs to explain the work in detail when the process of accepting new employees, so that incoming employees do not have to bear the work of employees who are not present. The company also has to look again at the problem of working hours because it is not in accordance with applicable government regulations ( 8 hours/day), if the working hours are excessive, employees can feel tired which causes employees to feel burdened.

2. The importance of mmaintain working relationships between employees so that they can motivate each other, please help if you need help in terms of work or even other things to create comfort at work. Then there is also the need to maximize HRD performance, for example for the counseling process, providing motivation, and so on. This is done to anticipate the impact of internal conflicts experienced by employees of PT Lutvindo Wijaya Perkasa

3. The provision of compensation should not only consider aspects of working period and level of education, but in certain conditions it is necessary to also consider aspects of workload. Because it is not necessarily employees with a long service period and a high level of education can do the work of employees with a heavy workload.

4. For further research, it is hoped that addother factors that affect employee turnover in PT. Lutvindo Wijaya Perkasabased on different characteristics and analytical tools. As well as using interview methods and open questionnaires in research, in order to obtain a more in-depth argument directly from the respondent to what is being studied.

\section{REFERENCES}

Suwatno and Donni Juni Priansa. 2016. HR Management in Public and Business Organizations. Bandung: Alphabeta

Stephen, Robbins 2015, Organizational Behavior, Salemba Empat Publishers, Jakarta

SP, Hasibuan, Malay. 2013. Human Resource Management. Jakarta: PT Bumi Aksara

Sofyandi, Herman. 2013. Human Resource Management. Yogyakarta. Graha Ilmu

Isyandi, HB, 2004 Human Resource Management in Global Perspective. Pekanbaru: unri press.

Edy Sutrisno, 2010. Human Resource Management, Third Edition, Kencana Prenada Media Group, Jakarta.

Ismail West Java, Isyandi, B., \& Susi. H. (2014). The Influence of Motivation and Leadership on Job Satisfaction and Its Implications on Work Discipline for Paramedics at the Regional General Hospital Dr. RM Pratomo, Rokan Hilir Regency. 22(September), $107-122$. 
Heprizal. (2013). The Effect of Compensation and Leadership on Employee Job Satisfaction At Pt. Eternal Independent Earth Pekanbaru

Rivai and Ella Sagala, (2013), Human Resource Management for Companies, Rajawali Pers, Jakarta.

Wiratama, Nyoman JA and Sintaasih, DK 2013. "The Influence of Leadership, Training and Work Discipline on the Performance of PDAM Tirta Mangutama Employees, Bandung Regency". Journal of Management, Business Strategy, and Entrepreneurship. Vol. 7, No.2.

Sutrisno, Eddy, (2016), Human Resource Management. Jakarta: Prenadamedia Group

Sunjoyo, et al, (2013). SPSS Application For Smart Research. Bandung: Alphabeta

Sunyoto, D. (2011). Human Resource Management. Yogyakarta: CAPS

Ghozali, Imam. 2011. Application of Multivariate Analysis with IBM SPSS Program. Edition7. Semarang : Diponegoro University

Sugiyono. 2013. Quantitative, Qualitative, and R\&D Research Methods. Bandung: Cv. Alphabet

Priyatno, Duwi. (2009). SPSS for Correlation, Regression and Multivariate Analysis. Yogyakarta: Media Style.

Setyaningdyah, Endang et al. 2013. The Effects of Human Resource Competence, Organizational Commitment and Ransactional Leadership on Work Discipline, Job Satisfaction and Employee's Performance. Interdisciplinary journal of contemporary research in business. Indonesia: Brawijaya University

Harlie, M. 2010. "The Influence of Work Discipline, Motivation and Career Development on the Performance of Civil Servants in the Tabalong Regency Government in Tanjung, South Kalimantan". Journal of Management and Accounting.Vol. 11 No. 2, October 2010; 117-124.

SP, Hasibuan, Malay. 2012. Human Resource Management. Jakarta: PT Bumi Aksara

Sutrisno, Edy. 2013. Human Resource Management, Fifth Edition. Yogyakarta: Prenada Media

Donni Junni Priansa 2014, HR Planning \& Development, Bandung Publisher: Alfabeta

Donni Juni Priansa. 2009. Sharia Business Management. Bandung: Alphabeta.

Nawawi, 2011, Human Resource Management: For Competitive Business, Gajahmada University Press, Yogyakarta

SP, Hasibuan, Malay. 2010. Human Resource Management. Jakarta: PT Bumi Aksara

Ahmad Sanusi. 2013. Educational Leadership: Renewal Strategy, Spirit of Service, Modern Management. Scholarly Feel: Bandung

Yukl, Gary (2014) Leadership In Organizations. Publisher: Pearson 
Aditya Reza, Regina. 2010. The Influence of Leadership Style, Motivation, and Work Discipline on Employee Performance at PT. Sinar Santosa Perkasa Banjarnegara. Semarang: Diponegoro University.

Nazir.Mohammad,Ph.D.(2011). Research methods. Jakarta : Ghalia Indonesia

Damodar N. Gujarati and Dawn C. Porter. 2012. Fundamentals of Econometrics. Jakarta: Four Salemba 